\title{
1. VEIN STRUCTURES OF THE PERU MARGIN, LEG 112 ${ }^{1}$
}

\author{
Nancy Lindsley-Griffin, ${ }^{2}$ Alan Kemp, ${ }^{3}$ and James F. Swartz ${ }^{4}$
}

\begin{abstract}
Numerous well-developed vein structures occur in Leg 112 cores from the Peru margin. Mud-filled dewatering veins occur in four styles: wide discrete gashes, veins along extensional microfaults, tension-gash arrays, and injections into tension gashes about slump-fold noses. Mud veins occur at shallow depths, less than 10 meters below sea floor (mbsf) in some cases, but some also were recovered as deep as $423 \mathrm{mbsf}$. Mud vein fill is slightly different in composition than the matrix and consists of a higher proportion of very fine silica, and in some cases, more authigenic carbonate or iron sulfide, transported into the veins by fluid flow. Clay minerals and many diatom fragments that are subhorizontal outside the veins have been rotated within the veins to parallel the vein walls.

Formation of mud veins occurs during sediment dewatering, perhaps initiated by the collapse of diatom frustules during compaction, or by overloading during downslope slumping and sliding. Complex multigenerational vein sets exhibit sequential development from wide discrete gashes to injections along microfaults to dense arrays of sigmoidal tension gashes, with progressive deformation of older veins during continued downslope movement. Critical factors required to produce mud veins are high sedimentation rates, relatively high porosity and resistance to compaction, and low permeability; vein preservation is enhanced by anoxic conditions that discourage bioturbation.

Carbonate-filled veins in Peru margin samples include tension gashes and wide, banded zones filled with calcite or dolomite spar; these probably result from filling of open fractures. Some sparry veins are crosscut by dewatering veins filled with calcareous mud, suggesting that the carbonate veins begin to form very early, before mud interbeds have dewatered.
\end{abstract}

\section{INTRODUCTION}

Vein structures were recovered at all of the sites occupied during Leg 112 along the Peru margin (Table 1). Although scientists on previous DSDP and ODP convergent margin legs have reported mud veins and similar structures (Table 2), better preserved vein structures were recovered during Leg 112 from shallower burial depths than during any previous leg. The excellent preservation of mud veins in Peru margin sediments probably results from the anoxic conditions under which many of these sediments were deposited.

\section{Terminology}

Veins have been defined as small $(<2 \mathrm{~mm})$ mud-filled features that crosscut bedding, commonly at a high angle, with no visible offset (Arthur et al., 1980; Carson et al., 1982). These veins may be planar, curviplanar, irregular, or anastomosing, and are darker and finer grained than the surrounding sediment (Table 2). Carbonate-filled veins may occur in calcareous sediments (Arthur et al., 1980; Carson et al., 1982; Shipboard Scientific Party, 1988d, 1988e). Healed fractures, commonly filled with mud veins, offset bedding and other primary features by $1 \mathrm{~mm}$ or less; these fractures have been termed "healed" because they are not open cracks and sediments or rocks have not broken along them during core recovery (Arthur et al., 1980; Carson et al., 1982). Healed fractures may be planar or irregular and appear in all orientations relative to bedding. Faults or microfaults have been

\footnotetext{
${ }^{1}$ Suess, E., von Huene, R., et al., 1990. Proc. ODP, Sci. Results, 112: College Station, TX (Ocean Drilling Program).

2 Department of Geology, Univ. of Nebraska, Lincoln NE 68588-0340.

${ }^{3}$ Department of Earth Sciences, The University, Southampton S09 5NH, England, United Kingdom.

${ }^{4}$ Department of Geology, Univ. of Nebraska, Lincoln, NE 68588-0340 now at School of Geology and Geophysics, Univ, of Oklahoma, Norman, OK 73019.
}

distinguished from healed fractures by offsets greater than 1 $\mathrm{mm}$, with some offsets up to $5 \mathrm{~cm}$ (Arthur et al., 1980; Carson et al., 1982). Here, we do not distinguish between healed fractures and microfaults because in Peru margin structures, healed fractures and microfaults are gradational with each other.

\section{METHODS OF STUDY}

This study combines shipboard observations made at the time of core recovery with shore-based observations using the petrographic microscope, the scanning electron microscope (SEM), and an energy dispersive system (EDS). Most of the thin sections for petrographic study were prepared from $2-\mathrm{cm}$ cubes of soft sediment that were impregnated with a low-viscosity Spurr resin (Spurr, 1969), using the technique described by Swartz and Lindsley-Griffin (this volume). Most of the carbonate samples and a few of the mudstone samples did not need impregnation.

\section{PERU MARGIN VEIN TYPES}

Peru margin veins occur in the following styles or patterns: (1) mud or silt filling wide discrete gashes; (2) mud along extensional microfaults; (3) sigmoidal mud veins filling enechelon tension-gash arrays; (4) injections of siliceous ooze or mud into tension cracks about slump-fold noses; (5) concentrations of dark stain in diffuse channels; (6) sparry calcite or dolomite veins in calcareous sediments. These four mud vein types and the calcite veins either offset or obliterate primary bedding or lamination; the fifth vein type passes across primary laminae without any disruption. Wide discrete gashes are broad, individual, mud-filled veins that typically originate in or just above coarse silt or sand layers. Their lower ends are narrow points, and they generally widen upward (PI. 1, Fig. 1). Some terminate upward in narrow points; others are cut off along sharp planes or fade out at their wide upper ends. These gashes may reach widths of 5 to $6 \mathrm{~mm}$ (PI. 1, Fig. 2; Table 1).

Short, subvertical microfault veins (PI. 1, Figs. 2, 3) offset layers in a normal sense, but thin out rapidly in both directions. These thin mud veins were apparently injected along 
Table 1. Vein structures of the Peru Margin, Sites 679 through 688.

\begin{tabular}{|c|c|c|c|c|c|c|c|c|c|c|}
\hline $\begin{array}{l}\text { Site } \\
\text { and } \\
\text { lctn. }\end{array}$ & $\begin{array}{l}\text { Water } \\
\text { depth } \\
\text { (mbsl) }\end{array}$ & $\begin{array}{l}\text { Strat. } \\
\text { depth } \\
\text { (mbsf) }\end{array}$ & $\begin{array}{l}\text { Dominant } \\
\text { lithology }\end{array}$ & Age & Orientation & Frequency, & Width & $\begin{array}{l}\text { Length } \\
(\mathrm{cm})\end{array}$ & Types & Description \\
\hline $\begin{array}{l}679 \\
\text { outer } \\
\text { shelf }\end{array}$ & $\begin{array}{l}440- \\
450\end{array}$ & $<10$ & DM & $\begin{array}{l}\text { Pleist. } \\
\text {-Plio. }\end{array}$ & $\begin{array}{l}\text { SV to SH } \\
\text { V }\end{array}$ & $\mathrm{U}$ & $1-6$ & $\begin{array}{l}4-10 \text { av. } \\
100 \text { max. }\end{array}$ & $1,2,3$ & $\begin{array}{l}3 \text { Types: } 1 \text {. along extensional micro- } \\
\text { faults } 2 \text {. en-echelon tension gashes } \\
3 \text {. wide discrete gashes. }\end{array}$ \\
\hline $\begin{array}{l}680 \\
\text { inner } \\
\text { shelf }\end{array}$ & 253 & 12.5 & DM & Quat. & SV to $\mathrm{V}$ & C & $1-2$ & $3-4$ & 1,2 & $\begin{array}{l}\text { Mud in en-echelon tension gashes; } \\
\text { rarely along ext. microfaults. }\end{array}$ \\
\hline $\begin{array}{l}681 \\
\text { inner } \\
\text { shelf }\end{array}$ & 152 & 17.5 & DM & Quat. & SV to V & R & $1-3$ & $3-4$ & 2 & $\begin{array}{l}\text { Rare mid-filled en-echelon tension } \\
\text { gashes. No wide discrete gashes or } \\
\text { ext. microfaults. }\end{array}$ \\
\hline $\begin{array}{l}682 \\
\text { mid- } \\
\text { slope }\end{array}$ & 3789 & 114 & $\begin{array}{l}\text { DM, } \\
\text { mast. }\end{array}$ & $\begin{array}{l}\text { upper } \\
\text { Mioc. }\end{array}$ & SV to $\mathrm{V}$ & VR & $1-4$ & $3-4$ & 1,3 & $\begin{array}{l}\text { Wide discrete gashes, infills } \\
\text { along ext. microfaults. }\end{array}$ \\
\hline $\begin{array}{l}683 \\
\text { mid- } \\
\text { slope }\end{array}$ & 3072 & 202 & DM & $\begin{array}{l}\text { upper } \\
\text { Plio. }\end{array}$ & SV to $\mathrm{V}$ & VR & $1-3$ & $3-4$ & 1,3 & $\begin{array}{l}\text { Mud-filled fractures just above } \\
\text { coarser beds; mud fills along ext. } \\
\text { microfaults. }\end{array}$ \\
\hline $\begin{array}{l}684 \\
\text { upper } \\
\text { slope } \\
\text { sed.pon }\end{array}$ & 4260 & 27 & $\begin{array}{c}\text { DM, } \\
\text { calc.DM }\end{array}$ & $\begin{array}{l}\text { Plio., } \\
\text { Miø. }\end{array}$ & SV to V & C & $1-3$ & $3-4$ & 1,3 & $\begin{array}{l}\text { Thin mud-filled veins and fluid escape } \\
\text { structures in Units III and V. Mud } \\
\text { veins along ext. microfaults. }\end{array}$ \\
\hline $\begin{array}{l}686 \\
\text { outer } \\
\text { shelf }\end{array}$ & 447 & 45 & DM & Quat. & SV to $\mathrm{V}$ & $\mathrm{R}$ & $1-3$ & $3-4$ & 1,3 & $\begin{array}{l}\text { Mud-filled veins that taper to } \\
\text { points at both ends. }\end{array}$ \\
\hline $\begin{array}{l}687 \\
\text { inner } \\
\text { shelf }\end{array}$ & 307 & 8.2 & DM & Quat. & SV to V & $\mathrm{R}$ & $1-3$ & $3-4$ & 1,2 & $\begin{array}{l}\text { Thin mud injections along microfaults, } \\
\text { multiple sets of sigmoidal tension } \\
\text { gashes. }\end{array}$ \\
\hline $\begin{array}{l}688 \mathrm{~A} \\
688 \mathrm{E} \\
\text { mid- } \\
\text { slope }\end{array}$ & $\begin{array}{l}3820 \\
3826\end{array}$ & $\begin{array}{r}26 \\
423\end{array}$ & $\begin{array}{l}\text { DM, } \\
\text { calc.DM }\end{array}$ & Quat. & $\begin{array}{l}\text { SV to V, } \\
\text { diagonal, SH }\end{array}$ & H & $1-3$ & $\begin{array}{l}4-6 \\
20 \text { max. }\end{array}$ & 1,2 & $\begin{array}{l}\text { Multiple sets, older are subparallel to } \\
\text { bedding, younger SV to V sigmoidal sets. }\end{array}$ \\
\hline
\end{tabular}

microfault planes when the faults formed, or shortly afterwards. The microfault veins in Plate 1, Figure 2 are analogous to the healed fractures and the microfaults of previous definitions (Arthur et al., 1980; Carson et al., 1982). Where welldeveloped, these microfault veins form densely packed subparallel arrays that divide the host sediment into vertically oriented lensoid rods and panels (Pl. 1, Fig. 4).

The sigmoidal mud veins that fill en-echelon tension-gash arrays consist of two or more generations of veins (PI. 2, Fig. 1). The oldest veins are commonly the most sigmoidal, the younger veins that crosscut them are less sigmoidal, and the youngest veins are nearly straight.

During post-cruise study, tension cracks were observed about the noses of several small slump-folds. Typically, these tension cracks are filled with material of the same composition as the interior of the slump-folds; the example in Plate 2, Figure 2, consists of diatom ooze, in the core of the fold, interbedded with gray amorphous silica and diatomaceous mud. These veins appear to represent injections of fluidized ooze from the overpressured slump-fold core (PI. 2, Fig. 3) through cracks that penetrated the less-permeable amorphous silica layers during or just after slumping.

In a few samples, diffuse stained channels of darker sediment are apparent under the petrographic microscope. Plate 2, Figure 3, shows a striking example of this vein type developed across a slump-fold. Unlike the other types of veins, these "ghost veins" do not disrupt primary bedding or lamination and do not have sharp walls. Microfossils continue across the vein wall without break (Pl. 2, Fig. 4). No major compositional change occurs within the stained areas, except for a slightly greater proportion of very fine black pyrite framboids and amorphous intergranular silica. Unlike the mud-filled veins, these faint diffuse channels exhibit no directional indicators to suggest upward flow, and they lack the strong preferred orientation seen within the mud veins.

Carbonate veins filled with calcite or dolomite spar occur in calcareous muds, limestones, and dolostones and, in some cases, are associated with carbonate mud veins (Pl. 3, Figs. 1, 2). In shape, some carbonate-filled veins resemble the mudfilled wide discrete gashes, microfault injections, and tensiongash arrays. Other carbonate veins consist of wide zones filled with subparallel growth bands and breccias that suggest repeated filling of open fractures by mineral-laden fluids (PI. 3, Figs. 3, 4).

\section{CHARACTERISTICS OF MUD-FILLED VEINS FROM THE PERU MARGIN}

\section{Vein Fill}

Mud-filled veins in Leg 112 cores are typically darker in color than the matrix (Pl. 4). Although the lighter-colored veins shown in Plate 4, Figure 1, appear to have transported material outward from a dolomitic layer, they more likely represent slurry transported along reactivated veins during drilling. Mud vein fill is similar in composition to matrix sediment and most commonly consists of diatomaceous mud with minor clay; clay minerals within the veins have the same composition as clays in the matrix. However, many Peru margin mud veins contain more authigenic carbonate than the surrounding sediment. Some veins are stained reddish brown to black, suggesting more iron oxides in the veins. At Site 685 , the veins observed in lithologic Unit IA (0-74 mbsf) include a 
number of extensional microfaults and wide discrete gashes filled with thin seams of dark bluish-black iron monosulfide and pyrite. Microscopic examination of mud vein fill indicates that it is finer-grained than matrix sediment and partially isotropic, suggesting that the veins are filled with a higher proportion of amorphous silica than adjacent matrix. Back-scattered electron imagery (BSEI) confirms that the veins are filled with a higher proportion of fines, and exhibit a lower porosity, than the matrix (Kemp, this volume). The finer grain size, combined with the increase in silica and iron sulfides, probably accounts for the darker color of most veins.

Vein walls are typically sharp and mark a distinct textural change (Pl. 4, Fig. 2). Primary structures, such as layering and laminae, are obliterated within most veins, except for the rare ghost veins that exhibit diffuse walls and contain poorly preserved primary features. Some microfossils are cut off at the vein walls, leaving slightly jagged edges indicative of brittle failure during vein formation; other microfossils are crosscut by vein walls without evidence of movement. Some diatoms that are bisected by vein walls appear to have undergone partial dissolution within the vein, leaving only a ghost of the original skeleton defined by trains of microscopic pyrite framboids. In some cases, veins have been deflected around large foraminifers (Pl. 4, Fig. 4), but have engulfed smaller foraminifers (Pl. 4, Fig. 2).

Most mud veins exhibit an internal structure that consists of bands of lighter and darker mud arranged subparallel to the vein walls (Pl. 4, Fig. 2). In some cases, these bands can be traced downward to a junction with the vein wall (PI. 4, Fig. 3 ), suggesting that they formed by removal of material from the vein wall and have been aligned into streamers by upward flow. Individual grains derived from sand or silt layers may form trains that bow upward, which is also suggestive of upward transport within the veins. Although the actual distance traveled may be no more than 0.5 to $2 \mathrm{~mm}$ in most veins, transport of 10 to $15 \mathrm{~mm}$ can be demonstrated in some cases (Pl. 4, Figs. 2, 3).

Clay minerals within mud veins are always aligned parallel to the vein walls. Some elongate diatom fragments within the veins are also oriented parallel to vein walls. This preferred orientation is enhanced under the petrographic microscope by the use of a gypsum plate and crossed nicols, allowing the sequence of vein formation to be deciphered from crosscutting relationships (Pl. 5, Fig. 1).

\section{Orientation and Size}

Most mud veins are oriented at a high angle to bedding $\left(70^{\circ}\right.$ to $85^{\circ}$ ), but in some intensely veined areas, small subhorizontal vein arrays occur between the larger subvertical veins ( $\mathrm{PI}$. 5, Fig. 2). Crosscutting relationships demonstrate that the subhorizontal veins formed before the subvertical veins. Veins are typically 0.5 to $2.0 \mathrm{~mm}$ thick, but rarely reach a maximum thickness of 5 to $10 \mathrm{~mm}$. Some large individual veins can be traced up to $1 \mathrm{~m}$ vertically within core sections (Pl. 1, Fig. 1), but more typically, individual veins thin out within a few centimeters. Lateral spacing between veins varies greatly, ranging from a minimum of less than $1 \mathrm{~mm}$ for the densely packed vein arrays (PI. 1, Fig. 3) to a maximum of at least $6 \mathrm{~cm}$ for thè large discrete veins. The maximum observable spacing is limited by the core width of $6 \mathrm{~cm}$ and may actually be much greater.

\section{Occurrence}

Although veins were recovered at all 10 sites drilled during Leg 112 , they dre common at only a few sites, more particularly, Sites $679,680,685,687$, and 688 . Even at these sites, more veins are preserved in some stratigraphic intervals than in others (Table 1).

Most of the veins observed during Leg 112 occur in finely laminated diatomaceous mud and diatom ooze and do not cross layers of coarse silt or fine sand (Pl. 5, Fig. 3). This characteristic suggests that veins form in sediments with high resistance to compaction, but where permeability is relatively low. Only rarely are Peru margin veins observed in intervals of poorly laminated, massive, or bioturbated muds.

As shown in Table 1, veins were first observed at stratigraphic depths of $8.2 \mathrm{mbsf}$ at Site 687 and $12.5 \mathrm{mbsf}$ at Site 680 ; depths of less than 50 mbsf were observed at seven other sites. At Site 679 , veins were first reported aboard ship at depths of 57 mbsf in Hole 679B and 56 mbsf in Hole 679D. These veins become common at depths of 60 to $68 \mathrm{mbsf}$, but are best developed in the diatomaceous mud unit (Unit II). Post-cruise examination of Core 112-679A-1H (at a depth of $<10$ mbsf) revealed well-developed arrays of mud veins 0.05 to $2 \mathrm{~mm}$ wide, 3 to $6 \mathrm{~cm}$ long across stratigraphic thickness, with a 1 to $4 \mathrm{~mm}$ spacing between veins. These veins are poorly preserved on the cut face of the core because of smearing of the fine laminae, but are readily visible on the upper and lower surfaces of a core fragment (PI. 1, Fig. 4), where they form a densely packed subparallel array that divides the host sediment into thin planar slabs.

\section{CARBONATE-FILLED VEIN STRUCTURES FROM THE PERU MARGIN}

Rare veins of calcite or dolomite spar occur in carbonate sediments and rocks from the Peru margin. Some of the sparry veins are crosscut by veins filled with carbonate mud (Pl. 3, Figs. 1, 2), which resemble the mud veins described above, except that they occur only in carbonate-rich host sediments. Many of the limestones and dolostones recovered during Leg 112 are actually breccias consisting of angular rock fragments in a matrix of crystalline calcite. A few of these carbonate rocks exhibit vein structures that postdate the brecciation; some of the fragments within breccias also contain veins that formed before brecciation.

Carbonate veins are typically lighter in color than the host sediment (Pl. 3, Fig. 1), unless they are stained with impurities (PI. 3, Fig. 3). These veins commonly include small amounts of impurities, such as pyrite or chert. The walls of carbonate veins are sharp and mark an abrupt change in texture, in some cases with concentric growth bands parallel to vein walls (PI. 3, Fig. 3). Many of the concentric growth bands in Plate 3, Figure 3 , are edged with radial crystals. Primary structures (such as laminae) are obliteratęd within the veins, and microfossils are not preserved.

Carbonate veins are oriented both subhorizontally and subvertically relative to bedding. Their widths, lengths, and spacings vary greatly; because of the sparse number observed, we were unable to characterize them accurately. The two styles shown in Plate 3 are typical: tension gashes and wide banded zones.

\section{VEIN STRUCTURES FROM ONSHORE LOCALITIES}

During a pre-cruise field trip, Leg 112 scientists visited the Miocene Pisco Formation of Peru, which consists of diatomites analogous to the siliceous mudstones of the offshore Peru margin. Although we did not observe vein structures like those recovered in Peru margin cores, dewatering pipes and related structures are common in the Pisco Formation, as are slump folds and extensional microfaults.

The Miocene Monterey Formation of California was visited by several Leg 112 scientists, including two of the authors 
Table 2. Vein structures from other localities.

\begin{tabular}{|c|c|c|c|c|c|c|c|c|c|}
\hline Margin & $\begin{array}{l}\text { Loca- } \\
\text { tion }\end{array}$ & $\begin{array}{l}\text { Leg: } \\
\text { Site }\end{array}$ & $\begin{array}{l}\text { Water } \\
\text { depth } \\
\text { (mbsl) }\end{array}$ & $\begin{array}{l}\text { Strat. } \\
\text { depth } \\
\text { (mbst) }\end{array}$ & $\begin{array}{l}\text { Daminant } \\
\text { lithology }\end{array}$ & Age & $\begin{array}{l}\text { Width } \\
\text { (mm) }\end{array}$ & $\begin{array}{l}\text { Length } \\
\text { (cm) }\end{array}$ & $\begin{array}{l}\text { Spacing } \\
\text { (mm) }\end{array}$ \\
\hline $\begin{array}{l}\text { Aleutian } \\
\text { Trench }\end{array}$ & $\begin{array}{l}\text { lower } \\
\text { slope }\end{array}$ & $18: 181$ & 3086 & 225 & Silty clay & 1. Pleist. & $1-2$ & $2-4$ & \\
\hline $\begin{array}{l}\text { Middle } \\
\text { America } \\
\text { Trench } \\
\text { (Mexico) }\end{array}$ & $\begin{array}{l}\text { upper } \\
\text { slope }\end{array}$ & $66: 489$ & 1240 & 100 & $\begin{array}{l}\text { Terrigenous } \\
\text { and silty } \\
\text { mudst. }\end{array}$ & $\begin{array}{r}\text { Miocene } \\
\mathrm{NNB}-2\end{array}$ & $<1.0$ & $\begin{array}{c}<0.5- \\
1.0\end{array}$ & \\
\hline \multirow{5}{*}{$\begin{array}{l}\text { Middle } \\
\text { America } \\
\text { Trench } \\
\text { (Guatemala) }\end{array}$} & $\begin{array}{l}\text { lower } \\
\text { slope }\end{array}$ & $67: 494$ & 5472 & 190 & $\begin{array}{l}\text { Diat. mud \& } \\
\text { mudst. }\end{array}$ & Quat. & $\begin{array}{r}0.5 \\
-2\end{array}$ & $<5$ & \\
\hline & $\begin{array}{l}\text { upper } \\
\text { slope }\end{array}$ & $67: 496$ & 2049 & 269.5 & $\begin{array}{l}\text { Sandy mud; } \\
\text { mud \& mudst. }\end{array}$ & m. Miø. & $<1.0$ & & $1-4$ \\
\hline & $\begin{array}{l}\text { upper } \\
\text { slope }\end{array}$ & $67: 497$ & 2347 & 162 & $\begin{array}{l}\text { nanno. mudst., } \\
\text { hemipel. mud, } \\
\text { diat. mud }\end{array}$ & $\begin{array}{l}\text { u. Plio.- } \\
\text { quat. }\end{array}$ & & & $1-5$ \\
\hline & $\begin{array}{l}\text { upper } \\
\text { slope }\end{array}$ & $84: 568$ & 2010 & 250 & silic. mudst. & 1.-m. Miø. & $1-2$ & $1-3$ & $\begin{array}{l}\text { "a few } \\
\text { mm" }\end{array}$ \\
\hline & $\begin{array}{l}\text { mid } \\
\text { slope }\end{array}$ & $84: 569$ & $\begin{array}{l}2744- \\
2795\end{array}$ & 120 & $\begin{array}{l}\text { ash-bearing } \\
\text { mud \& mudst. }\end{array}$ & 1.-m. Mioc. & $1-3$ & 10 & \\
\hline \multirow{4}{*}{$\begin{array}{l}\text { Lesser } \\
\text { Antilles } \\
\text { (Barbados) } \\
\text { Ridge }\end{array}$} & $\begin{array}{l}\text { lower } \\
\text { slope }\end{array}$ & $\begin{array}{l}\text { 78A: } \\
541\end{array}$ & 4940 & 163 & $\begin{array}{l}\text { nanno, mud, } \\
\text { mudst. }\end{array}$ & $\begin{array}{l}\text { 1. Plio.; } \\
\text { u. -m. Mioc. }\end{array}$ & $1-2$ & & $1-5$ \\
\hline & $\begin{array}{l}\text { lower } \\
\text { slope }\end{array}$ & $\begin{array}{l}78 \mathrm{~A}: \\
542 \mathrm{~A}\end{array}$ & 5016 & 164 & $\begin{array}{l}\text { marly nanno. } \\
\text { coze }\end{array}$ & u. Plio. & $1-2$ & & 1.5 \\
\hline & $\begin{array}{l}\text { Erench } \\
\quad \text { floor }\end{array}$ & $\begin{array}{l}110: \\
672\end{array}$ & 4975 & 106 & $\begin{array}{l}\text { calc. mud, } \\
\text { clayst. }\end{array}$ & 1. Plio & $1-3$ & $1-3$ & $10-20$ \\
\hline & $\begin{array}{l}\text { lower } \\
\text { slope }\end{array}$ & $\begin{array}{l}110: \\
673\end{array}$ & $\begin{array}{l}4661- \\
4680\end{array}$ & 29.8 & $\begin{array}{l}\text { clayst., } \\
\text { mudst., } \\
\text { calc. mudst. }\end{array}$ & $\begin{array}{l}\text { Plio. \& } \\
\text { older }\end{array}$ & $0.5-4$ & $3-6$ & $5-40$ \\
\hline \multirow[t]{4}{*}{$\begin{array}{l}\text { Lesser } \\
\text { Antilles }\end{array}$} & $\begin{array}{l}\text { lower } \\
\text { slope }\end{array}$ & 110: & 4550 & 150 & mudst. & uncertain & $1-4$ & $2-4$ & $2-40$ \\
\hline & & 674 & & $\overline{250}$ & sandstone & $\begin{array}{l}\text { m.-u. } \\
\text { Eocene }\end{array}$ & $1-3$ & $1-4$ & $2-10$ \\
\hline & $\begin{array}{l}\text { lower } \\
\text { slope }\end{array}$ & $\begin{array}{r}\text { 110: } \\
675\end{array}$ & 4994 & 360 & clayst. & 1. Miळc. & $1-2$ & 1 & \\
\hline & $\begin{array}{l}\text { lower } \\
\text { slope }\end{array}$ & $\begin{array}{r}110: \\
676\end{array}$ & 5053 & 271 & silic. mudst. & 1. Miœc. & & & \\
\hline \multirow[t]{5}{*}{$\begin{array}{l}\text { Japan } \\
\text { Trench }\end{array}$} & $\begin{array}{l}\text { lower } \\
\text { slope }\end{array}$ & $56: 434$ & 5986 & 250 & mudst. & $\begin{array}{l}\text { Plio, \& } \\
\text { older }\end{array}$ & $<0.5$ & & \\
\hline & $\begin{array}{l}\text { upper } \\
\text { slope }\end{array}$ & $\begin{array}{r}56: 438 \\
\& \quad 439\end{array}$ & $\begin{array}{l}1565 \\
1656\end{array}$ & 620 & diat. clayst. & 1.-m. Mioc. & $<0.5$ & 10 & $\begin{array}{c}\text { vari- } \\
\text { able }\end{array}$ \\
\hline & $\begin{array}{c}\text { midslope } \\
\text { terrace }\end{array}$ & $57: 440$ & 4515 & 254 & diat. clayst. & $\begin{array}{l}\text { 1. Pleist.- } \\
\text { u. Plio. }\end{array}$ & & & \\
\hline & $\begin{array}{l}\text { lower } \\
\text { slope }\end{array}$ & $57: 441$ & $\begin{array}{l}5644- \\
5655\end{array}$ & 260 & diat. clayst. & u. Plio. & & & \\
\hline & midslope & $\begin{array}{l}87 \mathrm{~B}: \\
584\end{array}$ & $\begin{array}{l}4078- \\
4094\end{array}$ & 385 & diat. mudst. & u. Miœc. & $\begin{array}{l}0.5- \\
3\end{array}$ & & $2-10$ \\
\hline \multirow[t]{2}{*}{$\begin{array}{l}\text { Nankai } \\
\text { Trough }\end{array}$} & $\begin{array}{r}\text { Shikoky } \\
\text { Basin } \\
\end{array}$ & $\begin{array}{l}\text { 87A: } \\
582\end{array}$ & 4879 & 634 & $\begin{array}{l}\text { hemipel. } \\
\text { mudst. }\end{array}$ & $\begin{array}{l}\text { 1. Quat. } \\
\text { NN19 }\end{array}$ & $<1.0$ & & \\
\hline & $\begin{array}{l}\text { Frontal } \\
\text { thrust }\end{array}$ & $\begin{array}{l}\text { 87A: } \\
583\end{array}$ & $\begin{array}{l}4618 \\
4677\end{array}$ & 370 & $\begin{array}{l}\text { hemipel. } \\
\text { mud }\end{array}$ & $\begin{array}{l}\text { 1. Quat } \\
\text { NN19 }\end{array}$ & $1-5$ & & $2-5$ \\
\hline $\begin{array}{l}\text { Mariana } \\
\text { Trench }\end{array}$ & $\begin{array}{l}\text { trench } \\
\text { slope } \\
\text { break }\end{array}$ & $60: 459$ & 4121 & 236 & $\begin{array}{l}\text { turbidites, } \\
\text { marly chalk, } \\
\text { vitric mudst. }\end{array}$ & 1.-m. Miø. & & & \\
\hline
\end{tabular}


Table 2 (continued),

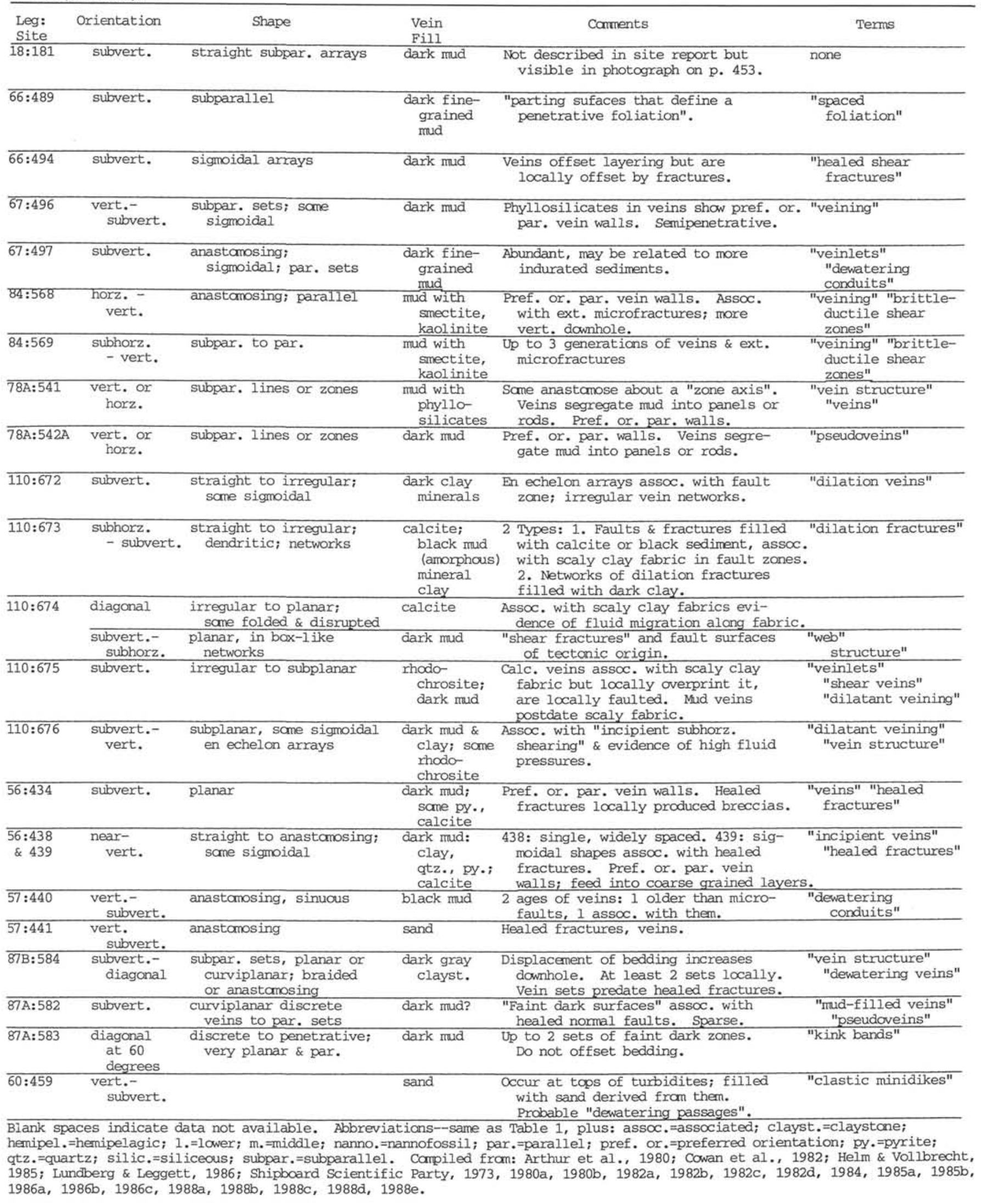


(Lindsley-Griffin and Kemp) in 1987. At two localities, mudfilled vein structures were observed within Monterey Formation diatomites (Pl. 5, Fig. 4). These structures are strikingly similar to the Peru margin vein structures in size, spacing, and geometry (Table 1) and probably developed similarly. Their presence within Miocene sediments suggests that vein structures may be fairly common and may be preserved within other ancient sediments. Features similar to vein structures have been reported from several onshore localities, including the Miocene Monterey Formation of California, the Neogene Miura Group of Japan, and similar rocks in Great Britain and Ecuador (Ogawa, 1980; Ogawa and Miyata, 1985; Lundberg and Leggett, 1986; Lundberg and Moore, 1986).

\section{VEIN STRUCTURES FROM OTHER CONVERGENT MARGINS}

In addition to the Peru margin, vein structures have been reported from the Aleutian margin, Japan Trench, Nankai Trough, Mariana Trench, Middle America Trench (Mexico and Guatemala), and the Lesser Antilles. As far as we know, vein structures were first recovered during DSDP Leg 18 (Aleutian Trench) at Site 181 (von Huene, pers. comm., 1988). Although not described, mud-filled veins can be seen in Figure 3 of the site report, Core 181-25-2 (Shipboard Scientific Party, 1973, p. 453).

The best-developed and greatest number of previously reported vein structures have been recovered from DSDP/ ODP drill sites located on upper trench slopes (Lundberg and Moore, 1986), but vein structures also have been recovered from drill sites located on the middle and lower slopes, trench floor, trench-slope break, and slope terrace (Table 2). Although Lundberg and Moore (1986) pointed out that vein structures have not been reported from passive margin sites or from nontectonic control sites, vein structures were recovered from ODP Site 672 (Leg 110) on the Lesser Antilles-Barbados margin far from strongly deformed sediments (Shipboard Scientific Party, 1988a). The characteristics of vein structures reported from previous DSDP and ODP legs (summarized in Table 2) were compiled mostly from the original site reports. Where vein characteristics were not described in the site reports, we have described features visible in core photographs in the site reports. The stratigraphic depth column gives the depth at which the veins were first reported, and the lithology and age columns give the composition and age of the sediments in which the veins occur. Dimensions (width, length, spacing) are approximate. Some of the terms that were applied to various vein structures are also indicated.

Although many different terms have been applied to these features, the broad similarity between them is striking (Tables $1,2)$. Repeatedly, the features are described as braided or anastomosing, as sigmoidal tension gashes, as being related to extensional microfractures and faults, or as consisting of material that is darker and finer-grained than the host sediment, but otherwise having the same composition. Clay minerals within the veins commonly exhibit preferred orientation parallel to vein walls.

\section{DISCUSSION}

Evidence from our structural and sedimentological studies, when combined with the vein characteristics described above, allows us to evaluate models for vein formation, as well as to reach some general conclusions about the tectonic and environmental significance of vein structures. The four styles of Peru margin mud veins are similar enough to have formed by the same mechanism, and we interpret them as dewatering conduits. The sparry carbonate veins apparently were deposited from water circulating in open fractures.

\section{Transport of Material Within Mud Veins}

The enrichment of many mud veins in authigenic carbonate, iron sulfides, or iron oxides relative to the surrounding sediment suggests migration of mineralized pore fluids into the veins. We interpret the present low porosity within mud veins (Kemp, this volume) as resulting from packing of fine amorphous silica into the veins by fluid flow. The selective dissolution of some diatom frustules within veins is additional evidence of fluid flow through the veins. Thus, these mud veins served as conduits for fluids during dewatering and diagenesis.

Mass transfer of material within mud veins is most obvious where veins cross light-colored layers of silt or ash. Under the petrographic microscope, silt grains appear to stream upward from coarse laminae toward the center of the vein (PI. 4, Figs. $3,4)$. This feature suggests upward transport of grains by fluids moving within the vein.

Although mud and silt have been transported along the veins in some cases, the evidence suggests that actual distances traveled are small. On the average, material is probably moved less than $5 \mathrm{~mm}$; the maximum observed transport distance is about 10 to $15 \mathrm{~mm}$ (Pl. 4, Fig. 2). The preservation of delicate microfossils like diatoms and foraminifers within mud veins (Pl. 5, Fig. 2) suggests that the larger particles undergo little or no transport. Thus, most vein fill probably consists mainly of in-situ sediment altered by slow fluid flow, as suggested by Lundberg and Karig (1986), but with the addition of fine amorphous silica and authigenic minerals.

The preferred orientation of clay minerals subparallel to vein walls is probably due to rotation of tiny individual flakes, rather than to some other mechanism, like pressure solution or recrystallization during faulting (Cowan, 1982). Our observations support this conclusion because the composition of the clay minerals in the veins is the same as that of clay minerals in the host sediment, and textural evidence of pressure solution is lacking. If preferred orientation resulted from fault movement, then reverse microfaults should exhibit well-developed veins having strong preferred orientation, but veins along reverse microfaults are not common (Tables 1,2).

\section{Association of Mud Veins with Mass Wasting}

The common occurrence of mud-filled veins along extensional microfaults (PI. 1, Figs. 2, 3) suggests that extension and dewatering are closely linked in time and space. Extension during downslope sliding and slumping must occur before diagenesis and lithification are well advanced; at the same time, the escape of fluids along extensional microfaults and vein structures must contribute to the lithification process.

At Site 685 , lithologic Unit IB (74.0-203.6 mbsf) is characterized by numerous folds, incipient fissility, and a pervasive dewatering vein fabric that is transitional between mudfilled microfaults and en-echelon mud-filled arrays. The close association between these structures suggests that they may have developed during downslope mass movement of sediments undergoing progressive dewatering and lithification. Figure 1A shows several sigmoidal, wide, discrete gashes that originate in a sandy bed, widen upward, and then terminate at the basal dècollement of a slump-folded zone. Figure 1B shows extensional microfault veins that terminate at the base of the overlying slump-folded zone. In both cases, either the dewatering veins formed before the slumping was completed, allowing their tops to be sheared off along the plane of dècollement, or they formed after slumping and terminate at the dècollement because its higher permeability allowed dewatering along the fault surface. In the latter case, the veins must have formed soon after the slump fold, because when the 

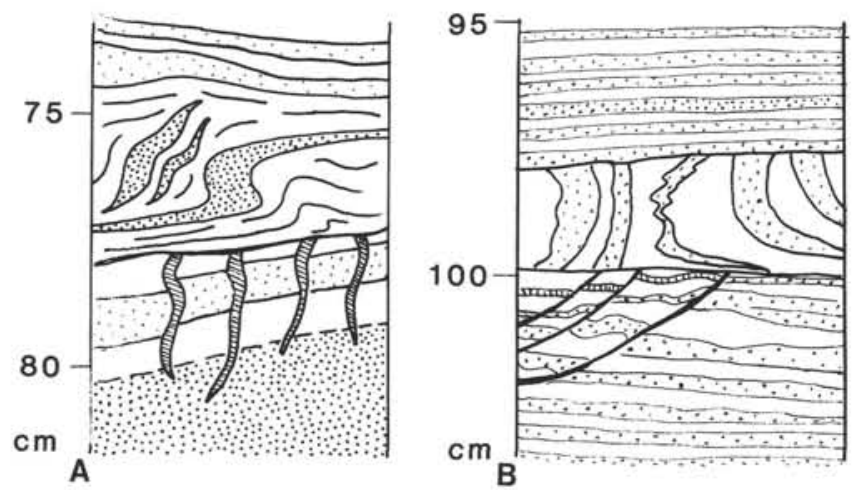

Figure 1. Sketches of relationships between slump folds and veins. A. Wide discrete gashes overlain by slump fold; veins terminate at the basal décollement of the slumped interval (Sample 112-687B-3H-2, $75-85 \mathrm{~cm}$ ). B. Thin mud injections in normal microfaults that fail to penetrate the overlying slump folded beds (Sample 112-686B-5H-5, 94-104 cm)

core was recovered, the veins terminated at the "healed" fault surface. The curved shapes of the sigmoidal veins in Figure 1A suggest that they were deformed by continued slumping.

The slump fold recovered in Hole $680 \mathrm{~B}$ is crosscut by several generations of sigmoidal tension gash veins, some localized along extensional microfaults (Pl. 2, Fig. 1). We interpret these relationships as recording the following series of events:

1. Downslope mass wasting of water-saturated muds produced the slump fold.

2. Loading from deposition of additional sediments caused compaction and dewatering, and the first set of veins formed along straight, near-vertical tension gashes. Fluid flow through the veins packed them with fine silica or authigenic carbonate, and flow was gradually shut off.

3. As deposition and downslope movement continued, the first vein set was slowly deformed into a sigmoidal shape by differential rotation.

4. When continued loading triggered another dewatering event, the second vein set crossed the deformed first set in a near-vertical orientation. Packing of the second vein set with fine silica again sealed off the dewatering veins, and they were deformed by continued slow downslope movement, while the first vein set was still further deformed.

5 . Each new set of near-vertical veins continued to develop until it in turn was sealed off, deformed, and overprinted by a new generation of veins.

\section{Timing of Mud Vein Development}

The occurrence of Leg 112 veins at very shallow stratigraphic depths suggests that vein structures can form very early in the history of the sediment. The high sedimentation rates typical of convergent continental margins like the Peru margin must contribute to early vein formation; the anoxic conditions at most of the Peru margin sites certainly enhanced vein preservation.

Some generalizations about sequential vein development can be made from crosscutting relationships observed in the Peru margin cores. Vein structures develop over a period of time as the sediment column thickens. At relatively shallow burial depths, veins typically occur first as isolated or widely spaced filled fractures (Pl. 1, Fig. 1), or as simple undeformed networks (PI. 1, Fig. 4). At greater burial depths, layersubparallel extension from gravity sliding of highly ductile soft sediment produces thinning and pulling apart of individual layers into boudins. Additional veins may form at this stage, taking advantage of zones of weakness in the thinned layers. As ductility decreases with progressive dewatering, extensional microfaults of a semibrittle character begin to form in the thin beds and laminae and serve as loci for microfault veins (Pl. 1, Fig. 2). As burial depth increases, succeeding generations of veins overprint the earlier veins, and eventually develop into anastomosing networks of sigmoidal veins filling en-echelon gashes (Pl. 1, Fig. 3).

\section{ORIGIN OF VEIN STRUCTURES}

Various models have been proposed for vein origin (Arthur et al., 1980; Carson et al., 1982; Cowan, 1982; Lundberg and Moore, 1982; Helm and Vollbrecht, 1985; Ogawa and Miyata, 1985; Ritger, 1985; Knipe, 1986). Most previously reported evidence supported a more or less passive dewatering during early extensional fracturing and faulting or downslope mass movement, with high fluid pressures but limited fluid flow.

An alternate hypothesis is that vein structures originate by tectonic loading as a sort of fracture cleavage, which was persuasively argued by Ogawa and Miyata (1985). Their supporting evidence included the occurrence of veins only in more lithified sediment, or near fault zones; control of vein style by lithology; and slickenlines or slickensides on vein walls (Ogawa and Miyata, 1985). However, we did not observe such evidence for the Peru margin vein structures.

\section{Origin of Mud Veins}

Significantly, mud veins are best developed in diatomaceous muds (Tables 1,2). The diatom oozes and muds of the Peru margin have high porosity, initial water content, and shear strength (Hill and Marsters, this volume). The diatomrich sediments resist compaction as long as the diatom framework remains intact. However, many diatoms in the veined intervals are flattened parallel to the laminations (Pl. 4, Fig. 4; Pl. 5, Fig. 2). Under sufficient sediment loading, some of the hollow diatom frustules collapse, expelling the water contained within them. The adjacent mud becomes fluidized and moves upward through any available weak point, generally along extensional microfaults. Fluid flow continues through the veins until packing of fine material into pores decreases permeability, and the veins are sealed off. Additional vein sets form each time additional sediment loading triggers another dewatering event.

The lack of mud veins within intensely bioturbated horizons could result from the difficulty of seeing them without a contrast in mud color or a visible break in primary layering. However, if vein formation is initiated by collapse of porous diatoms during sediment compaction, mud veins would be less likely in bioturbated sediments because the diatoms were already broken when sediment compaction began. If the strong primary fabric produced by alternating laminae of diatom ooze and diatomaceous mud is also a prerequisite for vein formation, this homogenization by bioturbation is another preventive factor, because the sediments can dewater evenly without the formation of distinct conduits. This conclusion is supported by the data reported by Hill and Marsters (this volume) that the massive, bioturbated diatomaceous sediments have a lower water content and shear strength than the well-laminated sediments, and that the lowest water contents and shear strengths occur within the more terrigenous sediments.

\section{Origin of Ghost Veins}

Although Kemp (this volume) has speculated that ghost veins may result from early fluid segregations that predate the formation of mud vein arrays, petrographic and structural 
evidence suggests that ghost veins more likely postdate the mud veins. The ghost veins in Plate 2, Figure 3, crosscut both the slump fold and the mud injections in tension cracks on the fold nose; thus, these ghost veins must have formed after the earliest dewatering occurred. In Plate 4, Figure 4, crosscutting relationships demonstrate that the dark mud vein is older; the younger vein appears to be intermediate between a mud vein and a ghost vein because it is lighter in color, with more diffuse vein walls that include some relict primary structure. These relationships imply that as the sediment becomes progressively dewatered, a sharply defined mud channel is less likely to form. Thus, these ghost veins may represent the latest stage of dewatering in which only fine amorphous silica and ions in solution were transported by fluids streaming slowly through pore spaces.

\section{Origin of Carbonate Veins}

Veins filled with sparry calcite were formerly interpreted as evidence for open fractures (Arthur et al., 1980). In Peru margin sediments, such carbonate deposition occurs early in diagenesis, before the sediments are completely dewatered, because some of the sparry veins are crosscut by later mud-filled dewatering veins. The lack of all primary internal features, including microfossils, supports the interpretation of these carbonate veins as fillings of open cracks, as does the growth of individual crystals in radial or concentric patterns. The association between multiple vein sets and carbonate breccias suggests a complex history of fracturing, brecciation, and fluid circulation in Peru margin carbonates.

Sparry calcite veins both predate and postdate calcareous mud veins in Sample 112-685A-50X-CC, 30-34 cm (PI. 3, Fig. 1,2). This limestone consists of finely laminated micrite mud containing trace amounts of fine chert and framboidal pyrite. Foraminifers are replaced by calcite spar, dolomite spar, minor chert, and rare pyrite. Vertical to subvertical veins composed of calcite spar with minor dolomite spar crosscut the primary laminae (PI. 3, Figs. 1, 2), but are themselves crosscut by two veins filled with dark calcareous mud. The mud-filled veins intrude along microfaults that define a small horst (Pl. 3, Fig. 1); normal sense displacement is approximately $2 \mathrm{~mm}$. Several calcite-dolomite spar veins crosscut the mud-filled vein (PI. 3, Fig. 2). We interpret these relationships to indicate the following events: (1) formation of tension gashes as open cracks soon after deposition of the sediment; (2) filling of open gashes with calcite-dolomite spar; (3) extensional microfaulting, accompanied by, or closely followed by, injection of fluidized calcareous mud during dewatering of the sediment; (4) formation of a second set of open gashes across the older spar and mud veins; and (5) filling of later tension gashes with calcite-dolomite spar.

Multiple sets of calcite veins in a dolomicrite are seen in Plate 3, Figs. 3 and 4 (Sample 112-684A-13X-CC [0-3]), depicted in the colored frontispiece of Suess, von Huene, et al. (1988). This fragment consists of yellow, foraminiferbearing diatomaceous dolomicrite with thin $(<1 \mathrm{~mm})$ gray layers of cryptocrystalline to amorphous silica. The foraminifers are replaced by dolomite spar. Diatom fragments and rare whole diatoms are important components of the dolomicrite, making up at least $10 \%$ of the matrix around the foraminifers. The calcite veins consist of dark gray to black calcareous mud and white calcite spar, in a finely banded zone that crosscuts and obliterates primary features, such as microfossils and layering (PI. 3, Fig. 4). These veins appear to have been injected with some force, because fragments of both the dolomicrite host rock and older vein sets have been plucked from the vein walls. Some fragments have been rotated, jumbled, and transported along the later veins (Pl. 3, Fig. 3). Crosscutting relationships between veins and vein breccias suggest at least three episodes of vein formation.

\section{Tectonic Setting of Vein Structures}

Most previously described mud vein structures have been attributed to dewatering processes; some have been attributed to tectonic processes. Dewatering veins and related structures, such as mud injections and diapirs, could occur in convergent margin sediments because of the combination of high sedimentation rates, low permeability, and tectonic stress. These factors are now widely recognized to result in high pore pressures, which contribute to forced dewatering and the resulting structures (Moore et al., 1982; von Huene and Lee, 1982; Westbrook and Smith, 1983; Shi and Wang, 1988; Pickering et al., 1988). Such factors might have contributed to formation of the Barbados dewatering veins, or to the veins recovered from Site 685 on the Peru margin.

However, most vein structures have been recovered from slope sediments or from basin deposits (Tables 1,2). The most important requirements for formation of vein structures are (1) diatom-rich sediments that resist compaction, (2) low permeability across layers, (3) rapid sedimentation, and (4) anoxic conditions.

The sigmoidal vein type has been noted previously as being typical of fault zones (Carson et al., 1982), but on the Peru margin this vein type was recovered at very shallow depths, where there was no evidence of faulting. Here, we suggest that sigmoidal veins form during repeated episodes of submarine mass wasting and slumping. Multiple sets of veins may continue to form until the sediment is sufficiently dewatered to fracture brittlely, so that vein structures may evolve into spaced foliation and, in some cases, may serve as loci for late-stage dewatering along fracture and fault surfaces. Thus, vein structures may be modified by later tectonic processes even though they began as tectonically passive dewatering features.

\section{CONCLUSIONS}

Peru margin vein structures formed mainly by sediment dewatering. The close association of dewatering veins with diatom-rich sediments (Tables 1,2) demonstrates a causal relationship between such sediments and vein formation. The major controlling factors are high porosity and water content, combined with high initial strength and resistance to compaction. Vein formation is triggered by collapse of diatom frustules to produce dewatering and flow of fluidized mud across layers. Rapid sedimentation and anoxic conditions contribute to vein formation by inhibiting bioturbation and the resultant dewatering and breakdown of diatom fabric.

The shallow occurrence of these veins and their close association with soft sediment deformation, such as distension and slump folding, suggest that vein formation may begin almost immediately after deposition, within a few to a few tens of meters of burial. Although slumping and sliding are not always necessary for vein formation, these can contribute to vein formation by producing sudden loading and by producing microstructures that localize veins.

Fluids flowed through the veins until packing of fine silica and deposition of authigenic minerals sealed off the conduits. Each vein set was short-lived, being overprinted by additional vein sets where later dewatering events occurred. The diffuse stained channels, or ghost veins, probably formed later than the mud veins and represent later stages of dewatering in which fluids were slowly streaming through pore spaces. 
Veins of calcite and dolomite spar represent fillings of open fractures. Such veins can form very early and may be overprinted by dewatering veins of calcareous mud.

\section{ACKNOWLEDGMENTS}

Participation in ODP Leg 112 and analysis of samples were supported by the National Science Foundation (USA) and the Natural Environment Research Council (UK). We thank two anonymous reviewers and $\mathrm{R}$. von Huene for their comments, which substantially improved the original manuscript.

\section{REFERENCES}

Arthur, M. A., Carson, B., and von Huene, R., 1980. Initial tectonic deformation of hemipelagic sediment at the leading edge of the Japan convergent margin. In von Huene, R., Nasu, N., et al., Init. Repts. DSDP, 56-57(Pt. 1): Washington (U.S. Govt. Printing Office), 569-613.

Carson, B., von Huene, R., and Arthur, M., 1982. Small-scale deformation structures and physical properties related to convergence in Japan Trench slope sediments. Tectonics, 1:277-302.

Cowan, D. S., 1982. Origin of "vein structure" in slope sediments on the inner slope of the Middle America Trench off Guatemala. In Aubouin, J., von Huene, R., et al., Init. Repts. DSDP, 67: Washington (U.S. Govt. Printing Office), 645-650.

Helm, R., and Vollbrecht, A., 1985. Brittle-ductile shear zones in slope sediments off Guatemala, Sites 568 and 569, Deep Sea Drilling Project Leg 84. In von Huene, R., Aubouin, J., et al., Init. Repts. DSDP, 84: Washington (U.S. Govt. Printing Office), 625632.

Knipe, R. J., 1986. Microstructural evolution of vein arrays preserved in Deep Sea Drilling Project cores from the Japan Trench, Leg 57. Geol. Soc. Am. Mem., 166:75-87.

Kagami, H., Karig, D. E., et al., Init. Repts. DSDP, 87: Washington (U.S. Govt. Printing Office), 797-808.

Lundberg, N., and Leggett, J. K., 1986. Structural features in cores from the slope landward of the Japan Trench, Deep Sea Drilling Project Leg 87B. In Kagami, H., Karig, D. E., et al., Init. Repts. DSDP, 87: Washington (U.S. Govt. Printing Office), 809-826.

Lundberg, N., and Moore, J. C., 1982. Structural features of the Middle America Trench slope off southern Mexico, Deep Sea Drilling Project Leg 66. In Watkins, J. S., Moore, J. C., et al., Init. Repts. DSDP, 66: Washington (U.S. Govt. Printing Office), 793814.

Lundberg, N., and Moore, J. C., 1986. Macroscopic structural features in Deep Sea Drilling Project cores from forearc regions. Geol. Soc. Am. Mem., 166:13-44.

Moore, J. C., Biju-Duval, B., et al., 1982. Offscraping and underthrusting of sediment at the deformation front of the Barbados Ridge: Deep Sea Drilling Project Leg 78A. Geol. Soc. Am. Bull., 93:1065-1077.

Ogawa, Y., 1980. Beard-like veinlet structure as fracture cleavage in the Neogene siltstone in the Miura and Bosa peninsulas, central Japan. Sci. Rept. Dept. Geol. Kyushu Univ., 13:321-327.

Ogawa, Y., and Miyata, Y., 1985. Vein structure and its deformational history in the sedimentary rocks of the Middle America Trench slope off Guatemala, Deep Sea Drilling Project Leg 84. In von Huene, R., Aubouin, J., et al., Init. Repts. DSDP, 84: Washington (U.S. Govt. Printing Office), 811-829.

Pickering, K. T., Agar, S. M., and Ogawa, Y., 1988. Genesis and deformation of mud injections containing chaotic basalt-limestonechert associations: examples from the southwest Japan forearc. Geology, 16.

Ritger, S. D., 1985. Origin of vein structures in the slope deposits of modern accretionary prisms. Geology, 13:437-439.

Scholle, P. A., 1978. Carbonate rock constituents, textures, cements, and porosities. AAPG Mem. 27.

Shi, Y., and Wang, C-Y., 1988. Generation of high pore pressures in accretionary prisms: inferences from the Barbados subduction complex. J. Geophys. Res., 93:8893-8910.
Shipboard Scientific Party, 1973. Site 181. In Kulm, L. D., von Huene, R., et al., Init. Repts. DSDP, 18: Washington (U.S. Govt. Printing Office), 449-499.

Shipboard Scientific Party, 1980a. Site 440: Japan Trench midslope terrace, Leg 57. In von Huene, R., Nasu, N., et al., Init. Repts. DSDP , 56-57: Washington (U.S. Govt. Printing Office), 225-317.

Shipboard Scientific Party, 1980b. Site 441: Japan Trench lower slope, Leg 57. In von Huene, R., Nasu, N., et al., Init. Repts. DSDP, 56-57: Washington (U.S. Govt. Printing Office), 319-354.

Shipboard Scientific Party, 1982a. Site 459: Mariana forearc. In Hussong, D. M., Uyeda, S., et al., Init. Repts. DSDP, 60: Washington (U.S. Govt. Printing Office), 309-369.

Shipboard Scientific Party, 1982b. Site 489. In Watkins, J. S., Moore, J. C., et al., Init. Repts. DSDP, 66: Washington (U.S. Govt. Printing Office), 107-150.

Shipboard Scientific Party, 1982c. Site 496: Middle America Trench upper slope. In Aubouin, J., von Huene, R., et al., Init. Repts. DSDP, 67: Washington (U.S. Govt. Printing Office), 143-192.

Shipboard Scientific Party, 1982d. Site 497: Middle America Trench upper slope. In Aubouin, J., von Huene, R., et al., Init. Repts. DSDP, 67: Washington (U.S. Govt. Printing Office), 193-243.

Shipboard Scientific Party, 1984. Site 541: Toe of the Barbados Ridge Complex. In Biju-duval, B., Moore, J. C., et al., Init. Repts. DSDP, 78A: Washington (U.S. Govt. Printing Office), 116-156.

Shipboard Scientific Party, 1985a. Site 568. In von Huene, R., Aubouin, J., et al., Init. Repts. DSDP, 84: Washington (U.S. Govt. Printing Office), 176-232.

Shipboard Scientific Party, 1985b. Site 569. In von Huene, R., Aubouin, J., et al., Init. Repts. DSDP, 84: Washington (U.S. Govt. Printing Office), 233-281.

Shipboard Scientific Party, 1986a. Site 582. In Kagami, H., Karig, D. E., et al., Init. Repts. DSDP, 87: Washington (U.S. Govt. Printing Office), 35-122.

Shipboard Scientific Party, 1986b. Site 583. In Kagami, H., Karig, D. E., et al., Init. Repts. DSDP, 87: Washington (U.S. Govt. Printing Office), 123-256.

Shipboard Scientific Party 1986c. Site 584. In Kagami, H., Karig, D. E., et al. Init. Repts. DSDP, 87: Washington (U.S. Govt. Printing Office), 257-390.

Shipboard Scientific Party, 1988a. Site 672. In Mascle, A., Moore, J. C., et al., Proc. ODP, Init. Repts., 110: College Station, TX (Ocean Drilling Program), 205-310.

Shipboard Scientific Party, 1988b. Site 673. In Mascle, A., Moore, J. C., et al., Proc. ODP, Init. Repts., 110: College Station, TX (Ocean Drilling Program), 311-388.

Shipboard Scientific Party, 1988c. Site 674. In Mascle, A., Moore, J. C., et al., Proc. ODP, Init. Repts., 110: College Station, TX (Ocean Drilling Program), 389-485.

Shipboard Scientific Party, 1988d. Site 675. In Mascle, A., Moore, J. C., et al., Proc. ODP, Init. Repts., 110: College Station, TX (Ocean Drilling Program), 487-507.

Shipboard Scientific Party, 1988e. Site 676. In Mascle, A., Moore, J. C., et al., Proc. ODP, Init. Repts., 110: College Station, TX (Ocean Drilling Program), 509-573.

Spurr, A. R., 1969. A low-viscosity epoxy resin embedding medium for electron microscopy. J. Ultrastructure Res., 26:31-43.

Suess, E., and von Huene, R., et al., 1988. Proc. ODP, Init. Repts., 112: College Station, TX (Ocean Drilling Program).

von Huene, R., and Lee, H., 1982. The possible significance of pore fluid pressures in subduction zones. AAPG Mem., 34:781-791.

Westbrook, G. K., and Smith, M. J., 1983. Long dècollements and mud volcanoes: Evidence from Barbados Ridge Complex for the role of high pore-fluid pressure in the development of an accretionary complex. Geology, 11:279-283.

Date of initial receipt: 28 September 1988

Date of acceptance: 3 August 1989

Ms 112B-130 


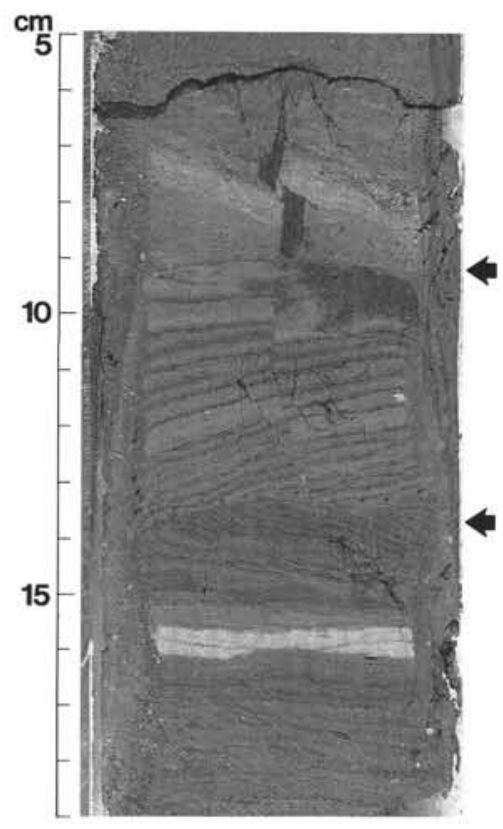

1

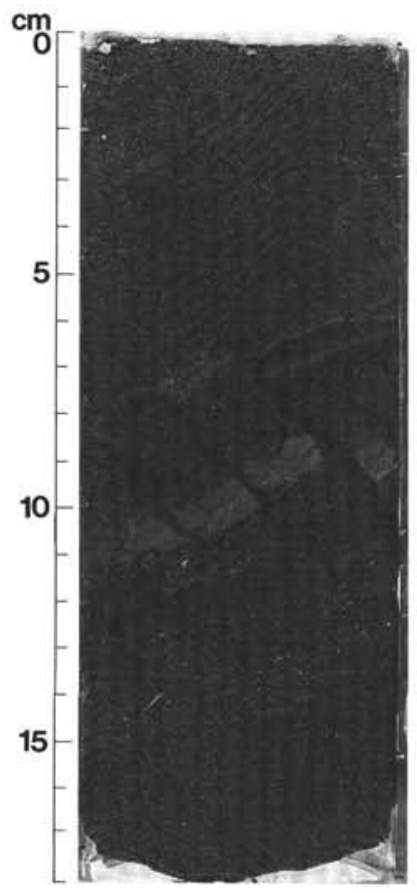

3

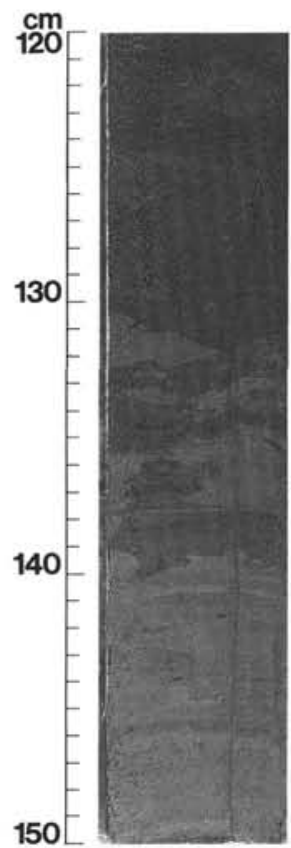

2

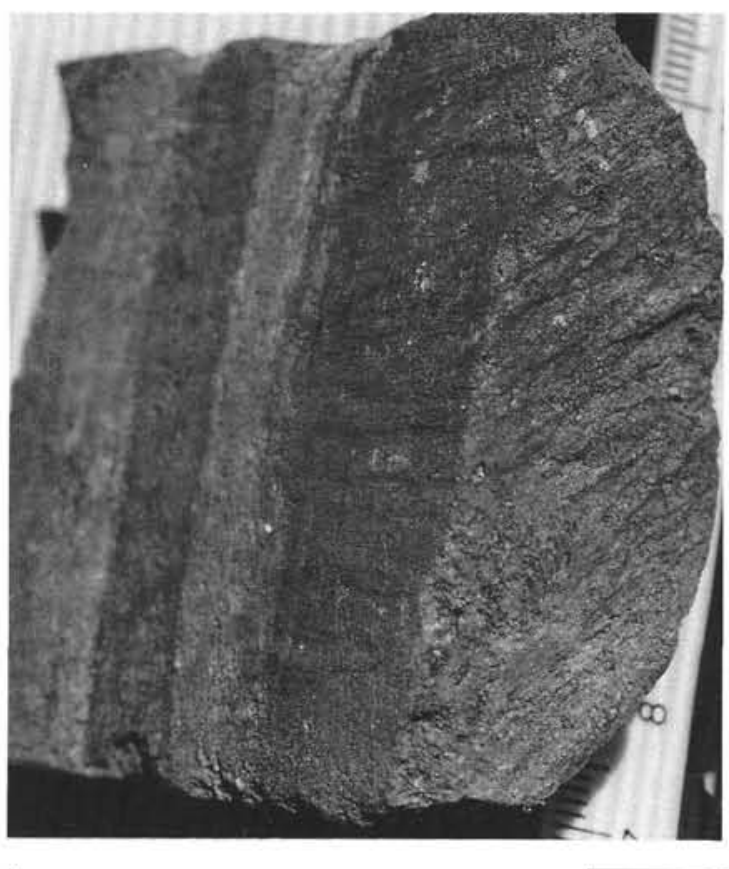

4

$1 \mathrm{~cm}$

Plate 1. Core photos of vein types. 1. Wide discrete mud vein at least $26 \mathrm{~cm}$ long in slump-folded diatomaceous muds and oozes. Offset of 1 to $2 \mathrm{~mm}$ is visible across the vein at 143 to $147 \mathrm{~cm}$. Small, mud-filled normal faults splay off from the large vein from 138 to $130 \mathrm{~cm}$ (Interval $112-680 \mathrm{~B}-8 \mathrm{H}-2,120-150 \mathrm{~cm}$ ). 2. Three drilling biscuits (boundaries at arrows) in diatomaceous mud and dolomite. Upper biscuit contains a wide discrete gash filled with mud and subsequently faulted. Lower two biscuits contain mud veins along extensional microfaults (Interval $112-682 \mathrm{~A}-12 \mathrm{X}-\mathrm{CC}, 5-19 \mathrm{~cm})$. 3. Mud veins along extensional fractures and microfaults in diatomaceous mud and ooze, with offset of 0.5 to 10 mm (Interval 112-679D-7H-7, 1-18 cm). 4. Well-developed mud vein array on cut face and end of core. The planar, subparallel to slightly braided veins divide the host sediment into tabular panels or rods (Section 112-679A-1H-3). 


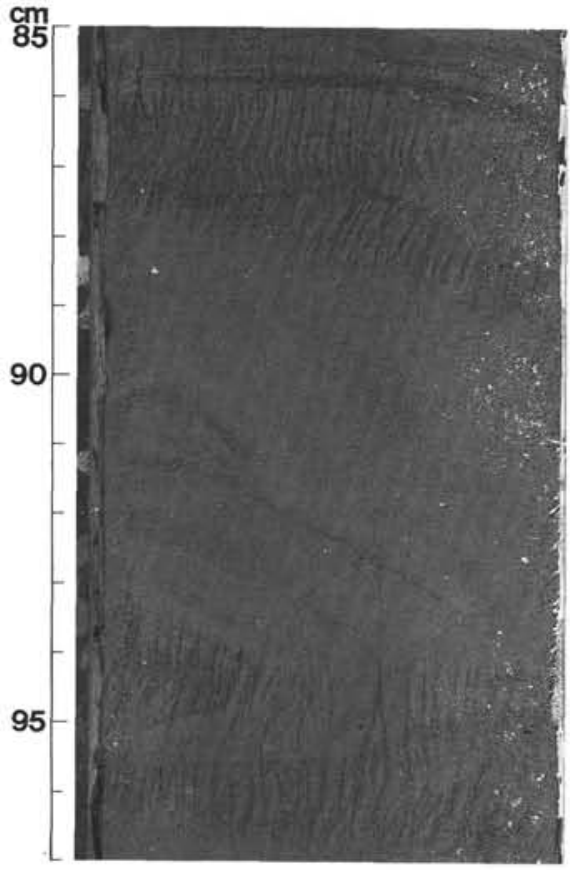

1

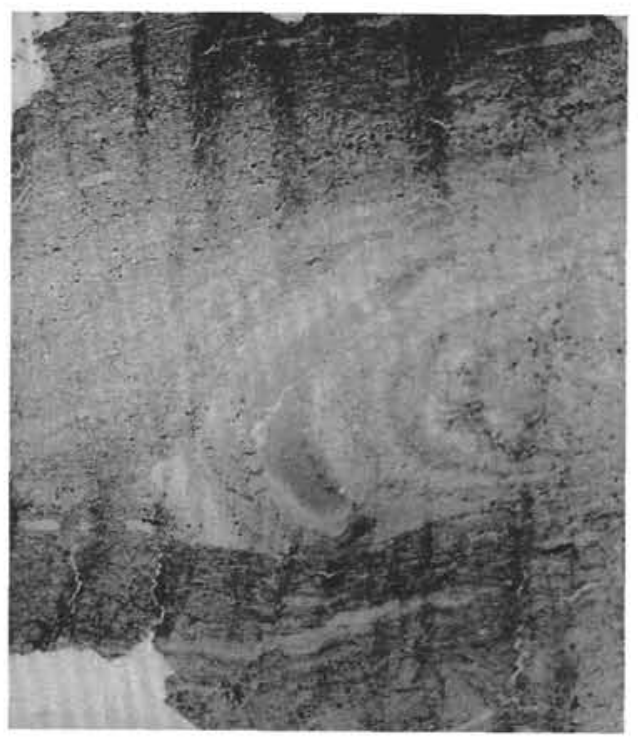

3

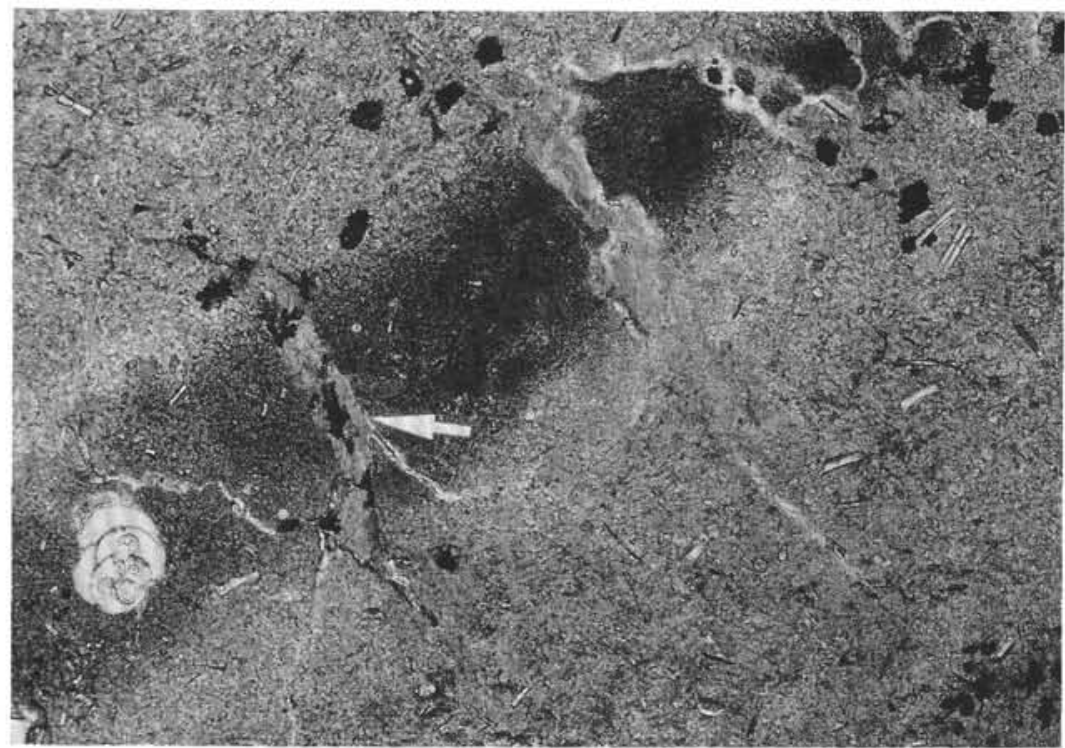

2

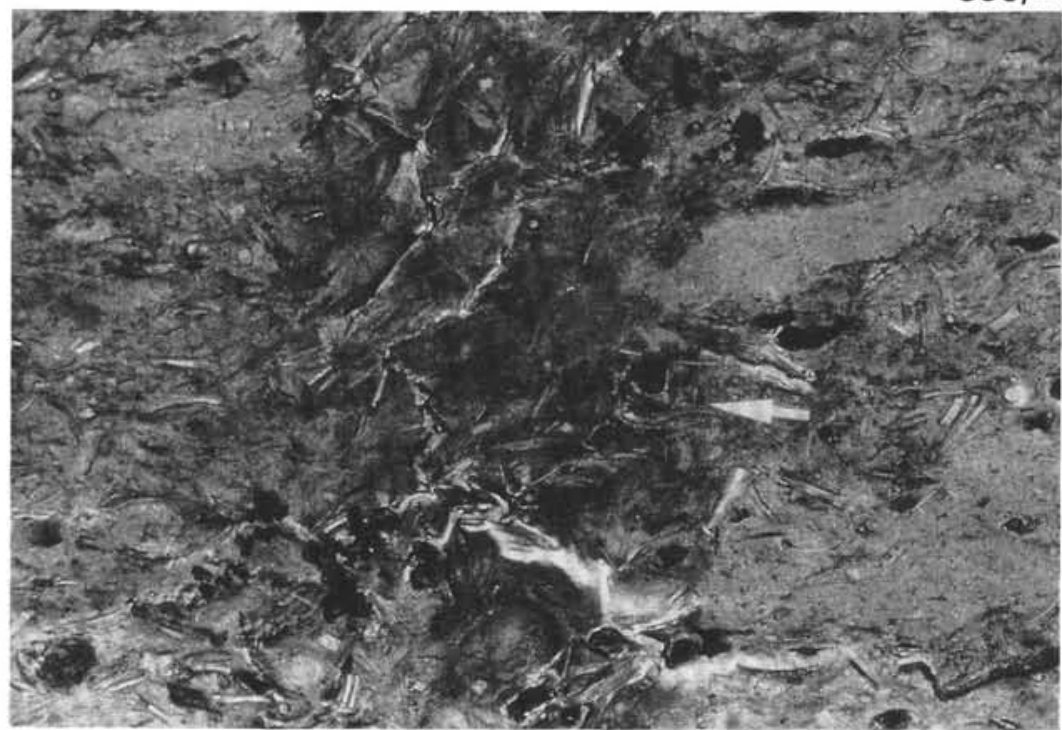

$\overline{300 \mu \mathrm{m}}$

Plate 2. Slump folds with veins. 1. Slump fold in diatomaceous mud and ooze with three generations of en-echelon tension-gash arrays. Sigmoidal older veins suggest shearing during continued downslope movement, then overprinting by less-deformed, youngest vein set (Interval $112-680 \mathrm{~B}-10 \mathrm{H}-2,86-96 \mathrm{~cm})$. 2. Veins filling tension cracks around a slump-fold nose in dark, fine-grained siliceous mud and light-colored diatom ooze. Black grains (arrow) are pyrite crystals and framboids (thin section photo, plane light, Sample 112-679D-2H-3, 90-93 cm). 3. Slump fold with the tension crack injections shown in Plate 2, Figure 2, and diffuse dark stained channels (photo of entire thin section, plane light, Sample 112-679D-2H-3, 90-93 cm). 4. Closeup of stained channel, showing diffuse nature of its boundary (arrow), and preservation of primary laminae and microfossil orientations within the vein (thin section photo, plane light, Sample 112-679D-2H-3, 90-93 cm). 


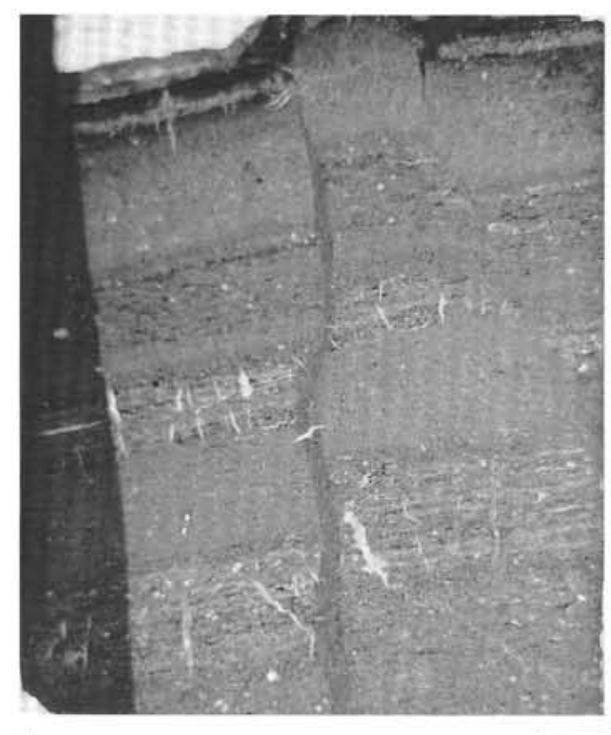

1

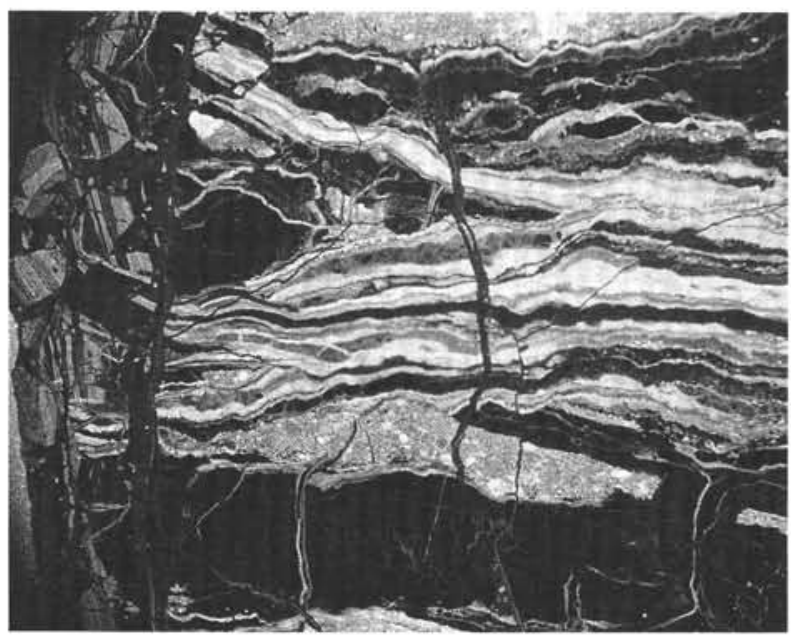

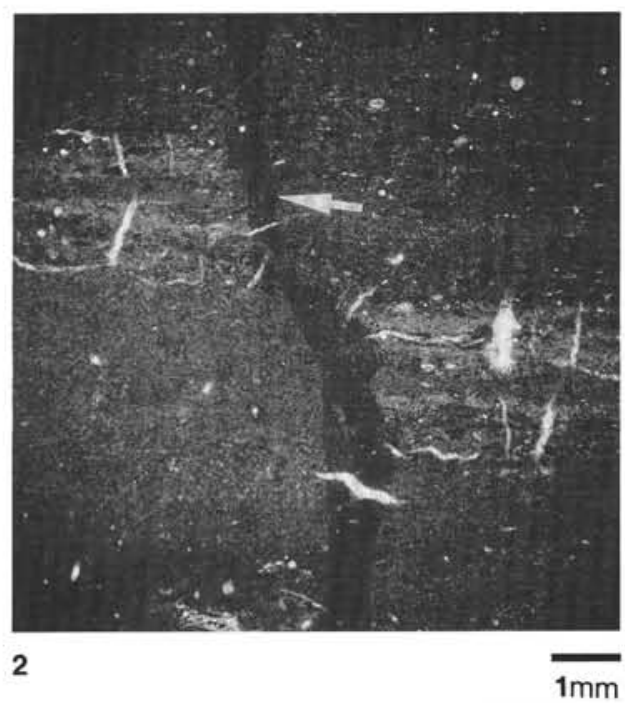

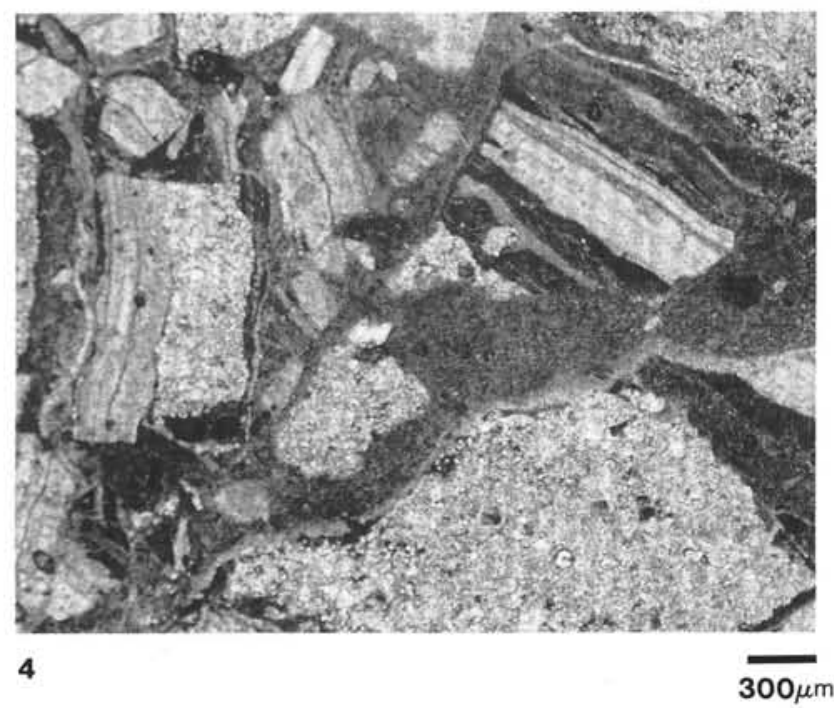

Plate 3. Carbonate veins. 1. Micritic limestone having calcite spar in tension gashes, crosscut by two calcareous mud veins that define a small horst, overprinted by later calcite spar-filled tension gashes. Edge of thin section is stained for calcite with Alizarin red-S (photo of entire thin section, plane light, Sample 112-685A-50X-CC, 30-34 cm). 2. Calcareous mud vein in limestone of Plate 3, Figure 1. Edge of dark mud vein (arrow) cuts off some of the light-colored sparite tension gash veins, but is overprinted by several later sparite veins. Sparite consists of calcite with minor dolomite (thin section photo, crossed nicols, Sample 112-685A-50X-CC, 30-34 cm). 3. Multiple generations of black and white calcite spar veins in diatom-bearing dolomicrite. Breccia zone at left consists of fragments of older vein material broken, transported, and rotated within a younger vein. Dark vertical veins filled with calcareous mud crosscut the sparry veins (thin section photo, plane light, Sample 112-684A-13X-CC, $0-3 \mathrm{~cm})$. 4. Closeup of calcite and calcareous mud veins in dolomicrite of Plate 3, Figure 3 . Fragments of host sediment and older veins are broken and rotated within a younger vein (thin section photo, plane light, Sample $112-684-13 \mathrm{X}-\mathrm{CC}, 0-3 \mathrm{~cm}$ ). 


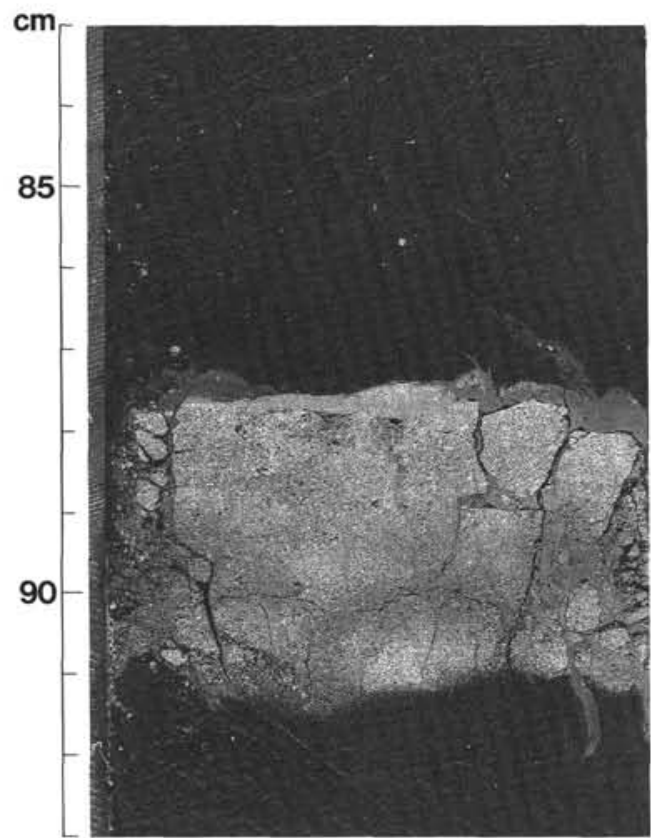

1

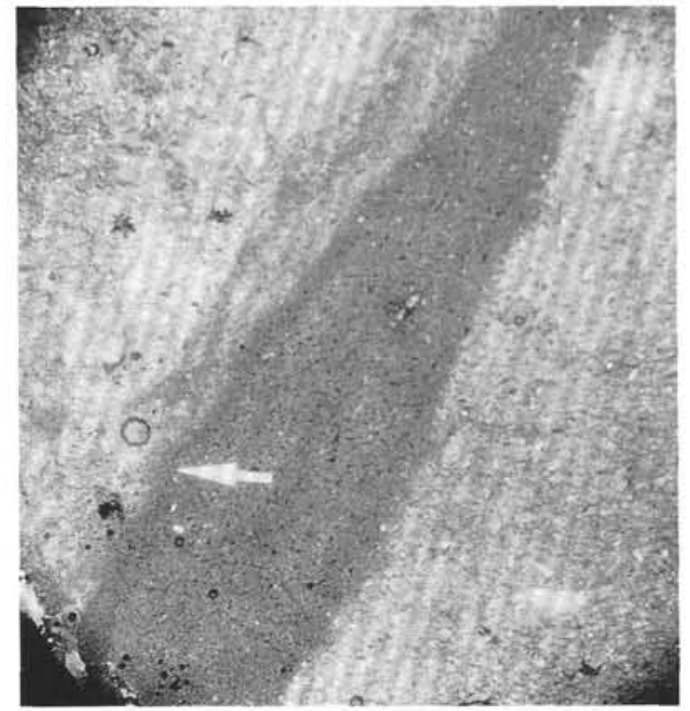

3

$1 \mathrm{~mm}$

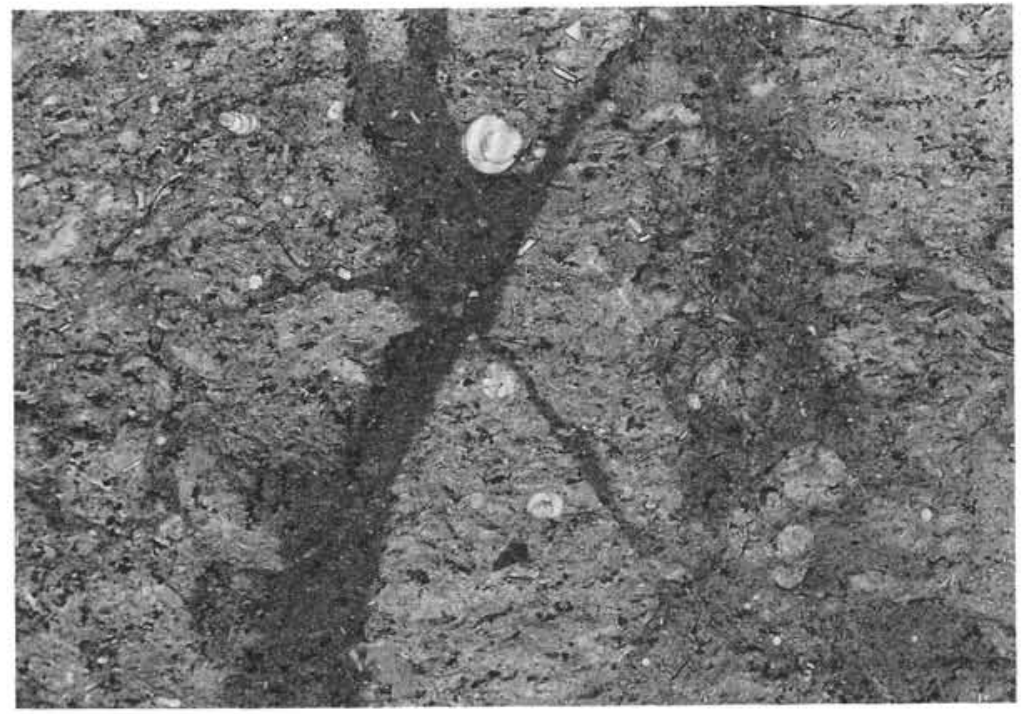

4

$\overline{300 \mu \mathrm{m}}$

Plate 4. Mud fill in veins. 1. Dark sigmoidal veins fill en-echelon tension gash arrays in diatomaceous mud. The color change adjacent to the light gray dolomite layer probably results from transport of slurry along reactivated veins during drilling (Interval 112-679B-10-5, 83-93 cm). 2. A 4-mm-wide braided diagonal vein that crosscuts and thus post-dates a thin vertical vein. Trains of silt grains within this vein are subparallel to the sharply defined vein wall (arrow). Light-colored sand grains and microfossils speckle the vein fill (thin section photo, plane light, Sample 112-679D-5H-3, 122-124 cm). 3. Silt streamer derived from vein wall (arrow) suggests upward transport of material within the vein (thin section photo, plane light, Sample 112-679D-6H-1,101-102 cm). 4. Dark mud vein bifurcates at large foraminifer, passing around it, rather than engulfing it. Most diatoms in the matrix have been flattened, but the foraminifers retain their original shapes. The younger vein at right is lighter, more diffuse, and retains more internal structure than the dark mud vein (thin section photo, plane light, Section 112-679B-8H-5). 

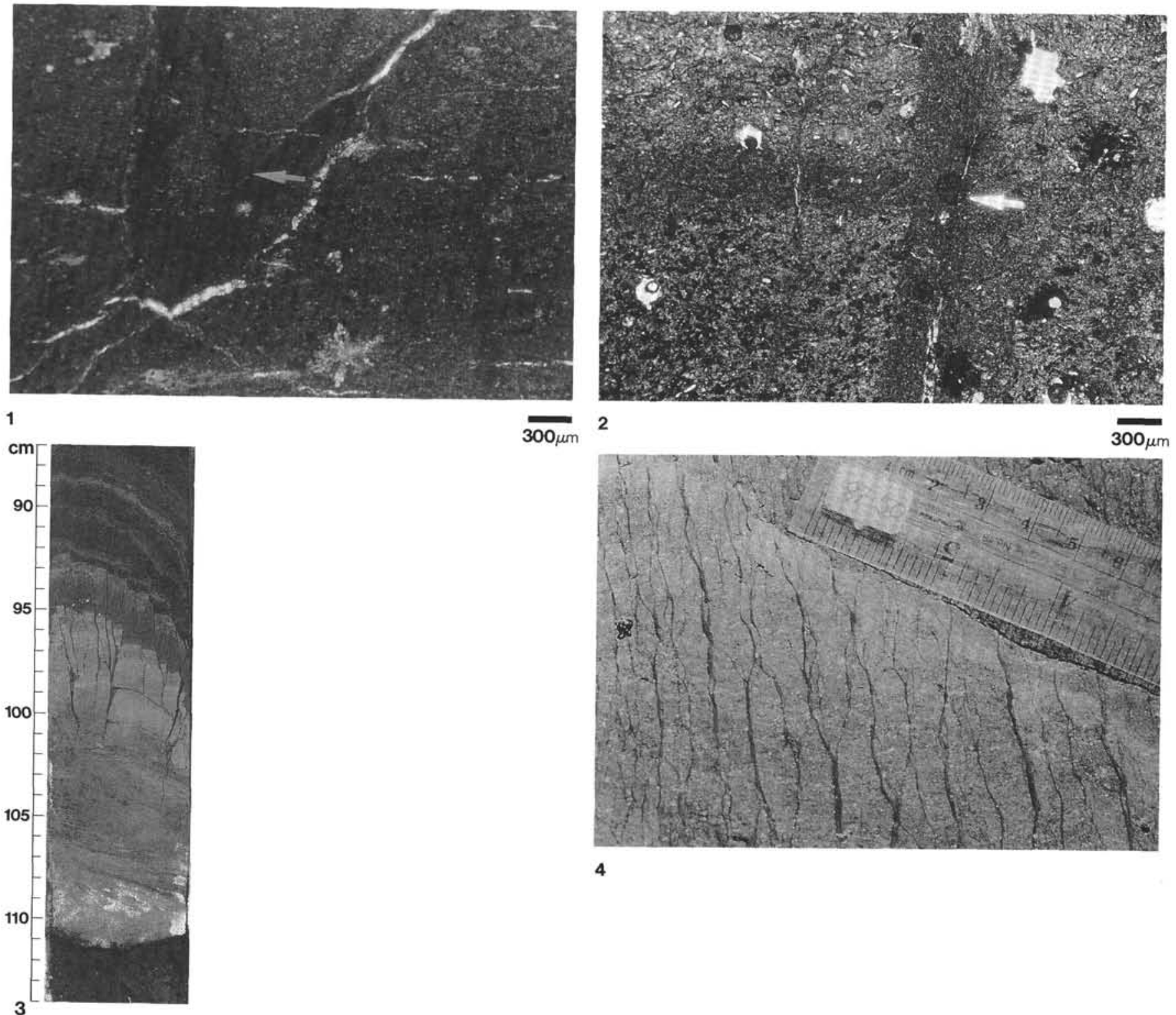

$300 \mu \mathrm{m}$

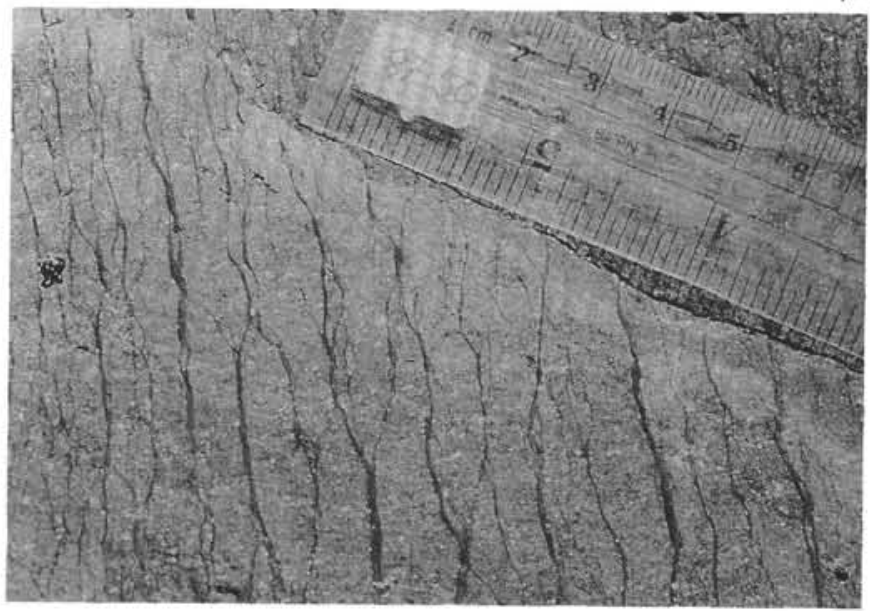

Plate 5. Mud vein sets and arrays from Peru margin and California. 1. Crosscutting relationships emphasized by preferred orientation of clay minerals within veins show that diagonal vein is younger than subvertical veins. Bright diagonal bands are open cracks (thin section photo, crossed nicols with gypsum plate, Sample 112-680B-10H-4, 69-71 cm). 2. Subhorizontal vein set crosscut by later subvertical vein in diatomaceous mud. Both exhibit strong preferred orientation of clay minerals parallel to vein walls. Microfossils within the veins are replaced by pyrite (arrow); some microfossils outside the veins are also pyritized (thin section photo, plane light, Sample 112-679B-12H-1, 134-136 cm). 3. Veins that originate in the upper part of a graded ash layer pass upward into diatomaceous muds and oozes, but do not pass downward into the coarser part of the bed. These veins occupy microfaults having displacements of 1 to $5 \mathrm{~mm}$ (Interval $112-679 \mathrm{~B}-10 \mathrm{H}-4,87-114 \mathrm{~cm}$ ). 4 . Mud-filled dewatering veins in diatomites of the Miocene Monterey Formation, Mussel Rock, California. 